\title{
The application of pedotransfer functions in the estimation of water retention in alluvial soils in Żuławy Wiślane, northern Poland
}

\begin{abstract}
The aim of the studies was the assessment of the usefulness of selected pedotransfer function for calculating the water retention of alluvial soils in Żuławy Wiślane. Żuławy Wiślane are an important area, both as far as agricultural production and environmental values are concerned. The analysis accounted for three models, i.e.: van Genuchten-Wösten, Varellyay and Mieronienko, Hewelke et al. Based on 122 dataset of alluvial soils from the Żuławy area, the statistical relationships between the measured values of total available water and values calculated for individual models were analysed. The studies carried out indicate that the analysed pedotransfer functions are characterized by different compatibilities with results obtained by means of direct measurement. The lowest average errors of fit were obtained for the Hewelke et al. and van Genuchten models.
\end{abstract}

Keywords: Soil water retention, water content of soils, matrix potential, total available water, multiple regression equations

\section{INTRODUCTION}

The water retention of soils is a functional relationship between the matrix potential and volumetric soil moisture content ( $\mathrm{pF}$ curve). In agricultural ecosystems, it determines the choice of crops, crop yields and necessary farming infrastructure and agro-technology (e.g. Hewelke et al. 2013, Czyż 2000). Knowledge of soil water retention is essential to assessing the water balance, especially in short time frames as well as predicting soil droughts and the course of flooding in a catchment. Due to the complicated and time-consuming process of the direct measurement of the $\mathrm{pF}$ curve, indirect methods are proposed, using relationships between the physical properties of soils and their moisture content. These methods are referred to as pedotransfer functions and their suitability were demonstrated by (e.g. Pachepsky and Rawls 2004, Guber and Pachepsky 2010, Vereecken et al. 2010). Studies on pedotransfer functions have been carried out by many authors (e.g. Trzecki 1974, 1976; Varallyay and Mironienko 1979, Van Genuchten 1980, Rawls and Brakensiek 1982, Varallyay et al. 1982, Walczak 1984, Carsel and Parrish 1988, Wösten et al. 1999, Vereecken et al. 1989, 2010; Schaap et al. 2001, Pachepsky and Rawls 2004, Walczak et al. 2004, Dexter et al. 2008, Gnatowski et al. 2006, 2010; Guber and Pachepsky 2010, Skalova et al. 2011, Puhlmann and von Wilpert 2012, Hewelke et al. 2013, 2015, 2017; Brogowski and Kwasowski 2015,
Lamorski et al. 2017, Oleszczuk et al. 2018). Among the developed models, we can distinguish continuous functions, enabling the moisture content of soil $(\theta)$ to be calculated for any given matrix potential (h), as well as discontinuous functions, making it possible to indicate the $\theta(h)$ relationships for characteristic $\theta$ values. Extensive compilations and an analysis of the models describing function for estimating water retention curves of soils can be found in particular in Guber and Pachepsky (2010). Empirical material for the particular solutions covers a very diverse soil sample set (collection) reaching as many as a few thousand, e.g. Rawls and Brakensiek (1982) - 5320 samples, Wösten et al. (1999) - 4030 samples.

Żuławy Wiślane is an important area, both as far as agricultural production and the natural environment are concerned. Due to the share of polders (approx. 45 thousand ha) and areas around polders (approx. 72 thousand ha), they pose a particular challenge to water management (Nowicki and Liziński 2004). Alluvial soils make up over $90 \%$ of soils in Vistula River Delta; they are characterised by high diversity, from very light to very heavy textured soils. The peculiarity of Żuławy alluvial soils results from the course of alluvial processes. The accumulation of Vistula river sediments under high humidity conditions causes specific soil compaction and further accumulation of organic matter. The Żuławy area is considered one of the most valuable and most fertile in Poland (Orzechowski et al. 2004). The morphological 
and retention characteristics of these soils have been presented by Brandyk (1988) among others. Nearly $40 \%$ of Żuławy Wiślane is in a polder system, with each polder characterized by significant agro-hydrological integrity. Because of this fact, knowledge of soil water retention comprises important information for rational water management both in the area of a given polder as well as the entire Żuławy water system.

The aim of the studies presented in the article was the assessment of the suitability of selected pedotransfer functions for calculating the retention abilities of Żuławy Wiślane (Vistula River Delta) alluvial soils.

\section{METHODOLOGY}

Three models of pedotransfers were analized: van Genuchten-Wösten (van Genuchten 1980, Wösten et al. 1999), Varallyay and Mironienko (Varallyay and Mironienko 1979, Varallyay et al. 1982) and Hewelke et al. (2013).

Van Genuchten (1980) describes the $\theta(h)$ dependency in the form of a continuous function expressed by a non-linear regression formula:

$$
\theta(h)=\theta_{r}+\frac{\theta_{s}-\theta_{r}}{\left(1+|\alpha \cdot h|^{n}\right)^{m}}
$$

where:

$\theta_{s}$ - saturated moisture content $\left[\mathrm{cm}^{3} \mathrm{~cm}^{-3}\right]$,

$\theta_{r}$ - residual moisture content $\left[\mathrm{cm}^{3} \mathrm{~cm}^{-3}\right]$,

$h$ - soil matrix potential $[\mathrm{cm}]$,

$\alpha, n, m=1-1 / n$ - parameters of $\mathrm{pF}$ curve $\left(\mathrm{cm}^{-1}\right)$,

$(-)$ respectively.

The values of $\theta_{s}$ as well as $\alpha$ and $\mathrm{n}$ can be calculated on the basis of empirical relationships provided by Wösten et al. (1999). Varallyay and Mironienko (Varallyay and Mironienko 1979, Varallyay et al. 1982) present the water retention characteristics of soil in the form of a discontinuous function expressed by the general formula:

$\theta_{p F}=b_{0}+b_{1} \cdot x_{1}+b_{2} \cdot x_{2}+b_{3} \cdot x_{1} \cdot x_{2}+b_{4} \cdot x_{1}^{2}+b_{5} \cdot x_{2}^{2}$

where:

$\theta_{p F}-$ soil moisture content for a respective value of the $\mathrm{pF}$ indicator,

$b_{0}, b_{1}, b_{2}, b_{3}, b_{4}, b_{5}-$ constant number coefficients for respective $\mathrm{pF}$ indicator and given soil texture classes, $x_{1}, x_{2}-$ variable coefficients indicating respective soil texture classes or bulk density.

The Varallyay and Mironienko's method allows for calculating soil moisture content for 9 characteristic values of the matrix potential on the basis of soil texture classes and bulk-density of soil for distinguished soil types.
The model described by Hewelke et al. (2013) comprises multiple regression equations and allows to define characteristic states of moisture content at 7 values of the matrix potential expressed by the $\mathrm{pF}$ indicator on the basis of a known content of selected particle fractions, bulk density and specific density of soil and organic matter content. For the value of the potential corresponding to $\mathrm{pF}=2.0$ and $\mathrm{pF}=4.2$ indicators, regression equations allowing for the moisture content of soil to be calculated take the form of:

$$
\begin{aligned}
\theta_{p F=2.0}= & \left(-18.7247+47.3855 \cdot \rho_{b}-21.073 \cdot r_{b}{ }^{2}-\right. \\
& 0.0855538 \cdot S P L A W+0.000200187 \cdot S P L A W^{2} \\
& -0.00000689571 \cdot P I A^{2} \cdot S P L A W+ \\
& \left.0.0240447 \cdot \rho_{p} \cdot S P L A W\right)^{2} \\
\theta_{p F=4.2}= & \left(-3.87197+17.8961 \cdot \rho_{b}-9.75799 \cdot \rho_{b}{ }^{2}-\right. \\
& 0.000323457 \cdot S P L A W^{2}+0.00618455 \\
& \rho_{b}{ }^{2} P I A-0.0000108911 \cdot P I A^{2} \cdot S P L A W+ \\
& \left.0.0433843 \cdot \rho_{b} \cdot S P L A W\right)^{2}
\end{aligned}
$$

where:

$$
\begin{array}{ll}
r_{b} & - \text { bulk density, }\left(\mathrm{Mg} \mathrm{m}^{-3}\right) \\
r_{p} & - \text { specific density }\left(\mathrm{Mg} \mathrm{m}^{-3}\right) \\
P I A & - \text { sand fraction contents for equivalent } \\
& \text { diamters } 1-0.1 \mathrm{~mm}(\%) ; \\
\text { SPLAW } & \text { - content of particles smaller than } \\
& 0.02 \mathrm{~mm}(\%) .
\end{array}
$$

Assessment of the presented methods in terms of the possibility of applying them to calculate the water retention of alluvial soils in Żuławy Wiślane was carried out assuming the total amount of water available to plants as a criterion (total available water - TAW), comprising the difference between soil moisture content at vales of $\mathrm{pF}=2.0$ and $\mathrm{pF}=4.2$. Based on the dataset of alluvial soils in the area of Żuławy, the statistical relationships between measured and calculated values for individual models were analysed. The studied dataset originates from 19 soil profiles of alluvial soils and covers 122 soil samples taken from various horizons. The undisturbed, standard $\left(100 \mathrm{~cm}^{3}\right)$ soil samples were collected in three replicates for determination of soil water retention characteristic. Additionally the disturbed samples (bags) were collected for measure specific bulk density, particle size distributions and loss-on-ignition, which represents soil organic matter. The analyses of soil particle size distribution were conducted by Casagrande in Prószyński modification areometric method and the soil textural classes were classified according to the previous Polish Society of Soil Science (Polish Soil Classification, 1989) standard. 
The retention curves were measured in the laboratory using reference methods (Klute 1986). The moisture content values in the range from 0 to 2 were determined on a sand table, whereas the amounts of water at the $\mathrm{pF}$ : 2.7, 3.4 and 4.2 were measured in pressure chambers.

Assessment of the possibilities of applying the analysed models to indicate total available water was carried out using regression analysis. The model is the better fitted to the empirical data the smaller the differences between the observed and calculated values. Statistical measures comprising the coefficient of determination $R^{2}$, root mean square error $S$, as well as the coefficient of random variation $V$ were applied to assess the compatibility between the measured and calculated values (Kot et al. 2011).

Coefficient of determination $R^{2}$ is a dimensionless quantity of the goodness of model fit and, in its basic form, is defined by the formula:

$$
R^{2}=\frac{\sum_{i=1}^{n}\left(\hat{\mathrm{y}}_{i}-\hat{\mathrm{y}}\right)^{2}}{\sum_{i=1}^{n}\left(\hat{\mathrm{y}}_{i}-\overline{\mathrm{y}}\right)^{2}}
$$

where:

$i$ - number of observation,

$n$ - total number of observations,

$y_{i}$ - measured value,

$\hat{y}_{i}-$ calculated value,

$\bar{y}$ - average value from sample.

The coefficient of determination indicates what part of the analysed phenomenon is explained by the estimated regression equation.

Root mean square error $S$ is defined by the formula:

$$
S=\sqrt{\frac{\sum_{i=1}^{n}\left(y_{i}-\hat{y}\right)^{2}}{n}}
$$

where:

$i$ - number of observation,

$n$ - total number of observations,

$y_{i}$ - measured value,

$\hat{y}_{i}$ - calculated value.

Root mean square error informs how much the actual measured values of the variable differ on average from theoretical values obtained using the considered model.
The coefficient of random variation $V$ indicates what of the average level of the modelled phenomenon the root mean square error comprises and is expressed by the formula:

$$
V=\frac{S}{\bar{y}}
$$

In connection with the above, $V$ specifies the average error made when calculating TAW in the analysed case using a model.

\section{RESULTS}

The summarised basic soil property statistic of the dataset have been presented in Table 1. The analysed series of Vistula alluvial soils is characterized by high diversity in terms of soil texture classes. It is represented by soils ranging from sands to clay soils. The following texture classes were distinguished: sands $-23.1 \%$, silts $-12.1 \%$, loams $-50.9 \%$ and clays $14.0 \%$. The content of individual fractions in the entire population is between 4 to $95 \%$ for sand $(1.0-0.1 \mathrm{~mm})$, silt $(0.1-0.02 \mathrm{~mm})$ from 2 to $84 \%$ and clay $(\leq 0.02 \mathrm{~mm})$ from 3 to $89 \%$. Analysed soil bulk density ranged from 1.21 to $1.59 \mathrm{Mg} \mathrm{m}^{-3}$, specific density from 2.34 to $2.72 \mathrm{Mg} \mathrm{m}^{-3}$ and the content of organic matter from 0.2 to $11.1 \%$.

The values of basic statistics characterizing the analysed soil water retention properties have been presented in Table 2. At the state close to soil saturation $(\mathrm{pF}=0.4)$, the average value of soil moisture content amounted to about $47.5 \%$ and gradually decreased reaching permanent wilting point value $(\mathrm{pF}=4.2)$ at about $18.4 \%$. In the group of sands, the majority of water occurs in macropores, which is correlated with decreasing moisture content in the scope of total water available to plants. Along with an increase in the contents of silt and clay fractions, the amount of gravitational water and, at the same time, the value of field water capacity $(\mathrm{pF}=2)$ increases. The coefficients of variability of the moisture content were observed to have increased (from about $12.9 \%$ to $56 \%$ ) along with an increase of the potential of the soil water.

TABLE. 1 . Summary statistics of basic soil properties of the dataset $(n=122)$

\begin{tabular}{lcccccc}
\hline Statistical measure & \multicolumn{2}{l}{ Content of particle [\%] } & & $\begin{array}{l}\text { Specific } \\
\text { density }\end{array}$ & Bulk density & $\begin{array}{l}\text { Organic } \\
\text { matter }\end{array}$ \\
\cline { 2 - 8 } & Sand & Silt & Clay & {$\left[\mathrm{Mg} \mathrm{m}^{-3}\right]$} & {$\left[\mathrm{Mg} \mathrm{m}^{-3}\right]$} & {$[\%]$} \\
\hline Mean value & 39.98 & 22.42 & 37.53 & 2.58 & 1.30 & 4.44 \\
\hline Standard deviation & 26.57 & 13.79 & 23.97 & 0.11 & 0.14 & 2.88 \\
\hline Minimum value & 4.00 & 2.00 & 3.00 & 2.13 & 1.12 & 0.20 \\
\hline Maximum value & 95.00 & 84.00 & 89.00 & 2.72 & 1.59 & 11.10 \\
\hline Coefficient of variability, CV [\%] & 66.46 & 61.51 & 63.85 & 4.26 & 10.76 & 64.86 \\
\hline
\end{tabular}


TABLE 2. Value of basic statistics of measured volumetric moisture content $\theta$ [vol. \%] of the soils at predefined values of $\mathrm{pF}$

\begin{tabular}{lccccccc}
\hline Statistical measure & $\theta_{p F}=0.4$ & $\theta_{p F}=1.0$ & $\theta_{p F}=1.5$ & $\theta_{p F}=2.0$ & $\theta_{p F}=2.7$ & $\theta_{p F}=3.4$ & $\theta_{p F}=4.2$ \\
\hline Mean value & 47.51 & 45.59 & 42.26 & 37.78 & 32.16 & 25.60 & 18.39 \\
\hline Standard deviation & 6.14 & 6.81 & 6.97 & 11.94 & 12.67 & 11.88 & 10.29 \\
\hline Minimum value & 35.91 & 31.01 & 15.03 & 6.01 & 3.54 & 2.05 & 1.05 \\
\hline Maximum value & 57.51 & 55.02 & 52.53 & 50.01 & 45.02 & 38.81 & 33.00 \\
\hline Coefficient of variability, CV [\%] & 12.92 & 14.94 & 21.22 & 31.60 & 39.41 & 46.42 & 55.96 \\
\hline
\end{tabular}

Water retention curves, identified directly and calculated according to the analysed models have been presented in Figure 1, also accounting for the course of the curve optimized according to the RETC programme (van Genuchten et al. 1991). The value of parameters for the van Genuchten formula were calculated using the Wösten's equation (Wösten et al. 1999) as well as the RETC programme (van Genuchten et al. 1991) optimizing the course of the $\mathrm{pF}$ curve determined empirically. The characteristics of $\theta_{s}, \alpha$ and $\mathrm{n}$ parameters for the analysed soil population have been presented in Table 3 .

Total available water (TAW) identified empirically for the entire population ranged from 6 to $33 \%$ by mean value $20.6 \%$ and coefficient of variability $30.3 \%$. The linear relationship between measured and calculated value of TAW for each of the models have been presented in Figure 2. Coefficient of regression $\beta$ for analysed relationship amounted from 0.87 to 1.14 .

a

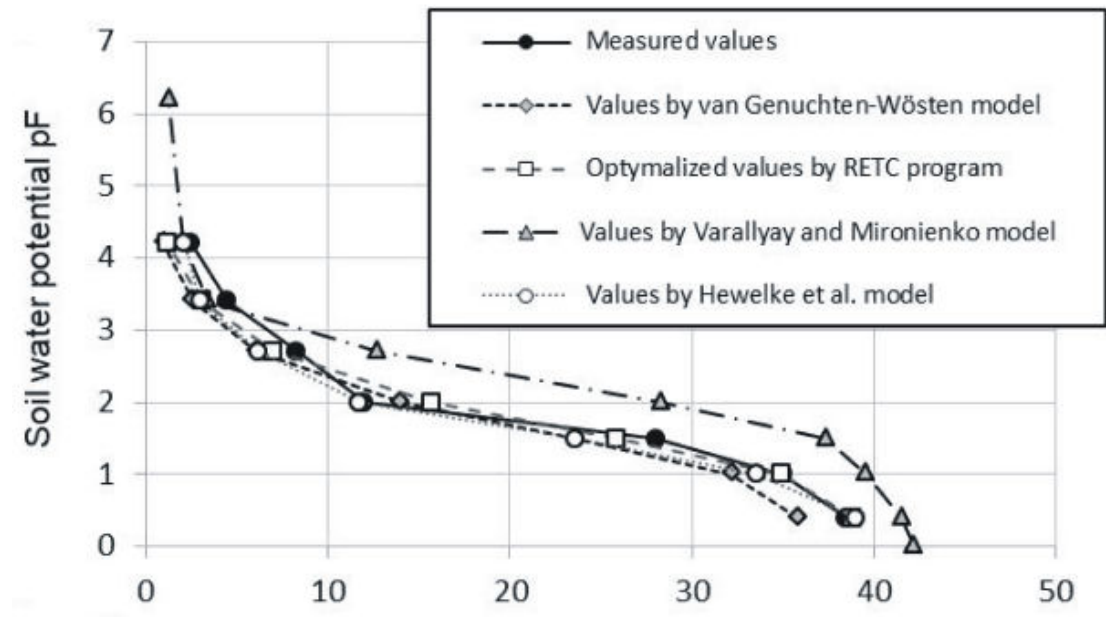

b

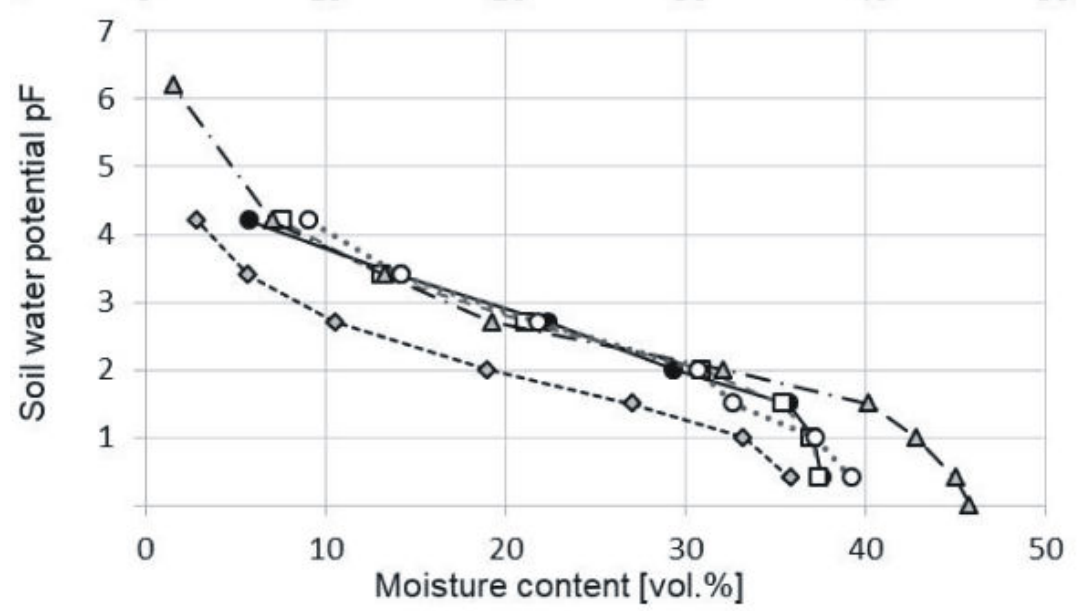

FIGURE 1. Water retention curves determined directly and calculated using the analysed models for: $\mathrm{a}$ - sandy soil and b - clay soil 
TABLE 3. Value of basic statistics of parameters $\theta_{\boldsymbol{s}}$, $\alpha$ and $\mathrm{n}$ for van Genuchten's formula

\begin{tabular}{|c|c|c|c|c|c|c|}
\hline \multirow[t]{2}{*}{ Statistical measures } & \multicolumn{2}{|c|}{ Parameter $\theta_{s}$} & \multicolumn{2}{|c|}{ Parameter $\alpha$} & \multicolumn{2}{|c|}{ Parameter $n$} \\
\hline & $\begin{array}{l}\text { Acc. to } \\
\text { Wösten }\end{array}$ & $\begin{array}{l}\text { Acc. to } \\
\text { RETC }\end{array}$ & $\begin{array}{l}\text { Acc. to } \\
\text { Wösten }\end{array}$ & $\begin{array}{l}\text { Acc. to } \\
\text { RETC }\end{array}$ & $\begin{array}{l}\text { Acc. to } \\
\text { Wösten }\end{array}$ & $\begin{array}{l}\text { Acc. to } \\
\text { RETC }\end{array}$ \\
\hline Mean value & 45.43 & 47.50 & 0.0566 & 0.0420 & 1.3271 & 1.2555 \\
\hline Standard deviation & 4.89 & 4.69 & 0.0091 & 0.0977 & 0.1798 & 0.2247 \\
\hline Minimum value & 34.54 & 36.88 & 0.0265 & 0.0015 & 1.1515 & 1.0819 \\
\hline Maximum value & 53.86 & 56.55 & 0.0757 & 0.9475 & 1.9065 & 2.4381 \\
\hline Coefficient of variability, CV [\%] & 10.76 & 9.87 & 16.15 & 237.79 & 13.55 & 17.89 \\
\hline
\end{tabular}

Van Genuchten - Wösten

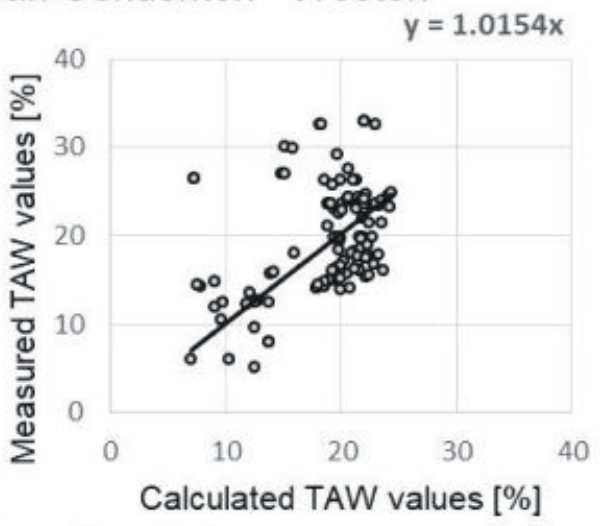

Hewelke et al.

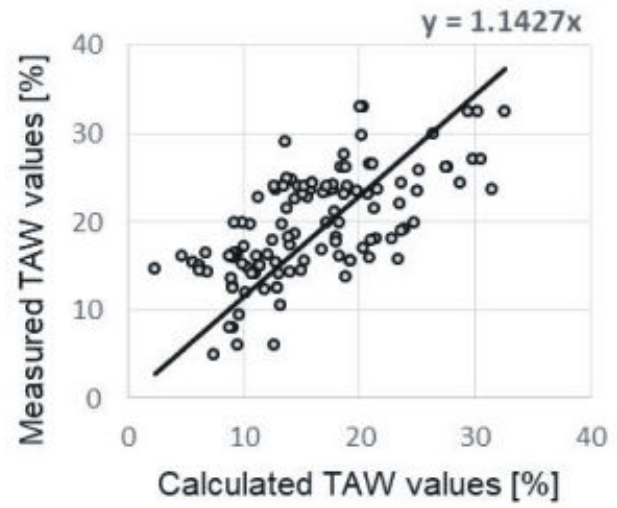

Varallyay and Mironienko

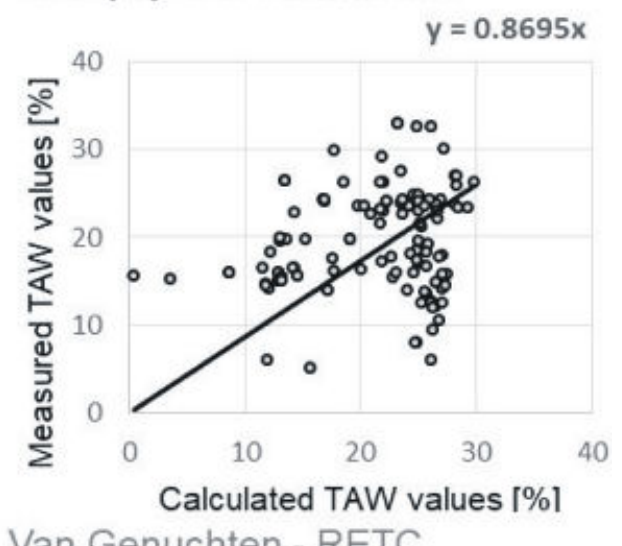

Van Genuchten - RETC

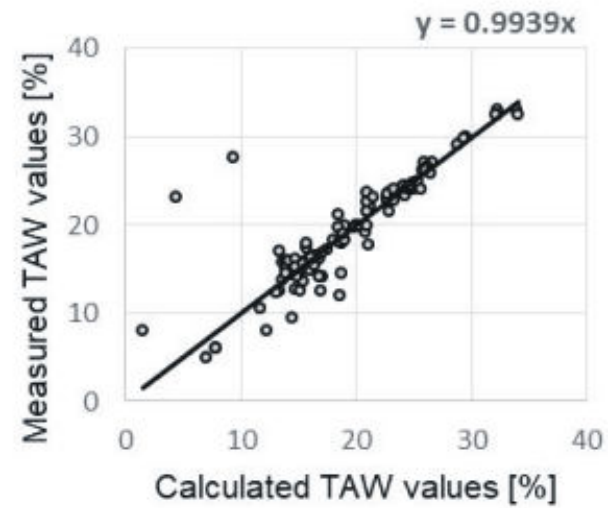

FIGURE 2. Relationship between measured and calculated (by analysed models) values of total available water (TAW)

\section{DISCUSSION}

The analysis of the soil texture classes, soil bulk and specific density and content of organic matter confirm that the studied population of soil samples is characterized by significant variation of physical properties. These properties decide about the abilities of the soil to retain water and are usually applied as explanatory variables in pedotransfer functions (e.g. Trzecki 1974, 1976; Walczak 1984, Vereecken et al. 1989, Wösten et al. 1999). Significant variation in retention capacity is confirmed by the laboratory results of soil water desorption curves. In the analysed soils, the amount of water available to plants ranged from $6 \%$ for sands to $33 \%$ for clays. The obtained results of the soil retention capacities are generally in accordance with those provided in literature regarding alluvial soils of the Vistula River Delta and indicate their significant morphological and spatial diversity (e.g. Brandyk 1988).

The courses of $\theta(h)$ functions approximate the measured course in various degrees calculated on the basis of the analysed models. Approximation of the measureved curve is rather in agreement for sandy soils for all of the analyzed models. For heavier soils, these differences may be significant (Fig. 1). Comparing the $\alpha$ parameters (Table 3 ) indicates significant differences between the values calculated 
TABLE 4. Statistical measures of assessing the compatibility of calculated and measured TAW values for analysed models

\begin{tabular}{lllll}
\hline Statistical measure of assessment & $\begin{array}{l}\text { Van Genuchten } \\
- \text { Wösten }\end{array}$ & $\begin{array}{l}\text { Varallyay - } \\
\text { Mironienko }\end{array}$ & Hewelke et al. & $\begin{array}{l}\text { Van Genuchten - } \\
\text { RETC }\end{array}$ \\
\hline Coefficient of regression $(\beta)$ & 1.0154 & 0.8695 & 1.1427 & 0.994 \\
\hline Coefficient of determination $\left(R^{2}\right)$ & 0.425 & 0.229 & 0.645 & 0.884 \\
\hline Root mean square error $(S)$ & 5.30 & 7.61 & 4.29 & 2.85 \\
\hline Coefficient of random variation $(V)$ & 0.27 & 0.39 & 0.22 & 0.15 \\
\hline
\end{tabular}

according to Wösten's formula and were obtained according to the RETC programme on the basis of the measured $\mathrm{pF}$ curve. Based on the whole population, it can be concluded that variability of the $\alpha$ parameter calculated according to Wösten's formula is low and characterized by a coefficient of variability $\mathrm{CV}=16.2 \%$, while $\alpha$ obtained on the basis of the measured $\mathrm{pF}$ curve is characterized by a coefficient of variation of as much as $237.8 \%$ (Table 3 ). This means that the values of the $\theta(h)$ function calculated using Wösten's formula may differ significantly from values obtained on the basis of measurement. The observed situation is characteristic for empirical models, where fit to actual values is determined by the parameters of the model.

The statistical measures of assessing the compatibility between measured and calculate TAW value (Fig. 2) have been given in Table 4. The presented measures show that the highest value of $R^{2}$ for relationships between the measured and calculated TAW values were obtained for the Hewelke et al. model (2013) i.e., $R^{2}=0.645$ at $\beta=1.143$. Van Genuchten's model with Wösten's coefficients is characterized by slightly worse fit, $R^{2}=0.425$ at $\alpha=$ 1.015. If parameters identified on the basis of the measured retention curve (RTEC programme) are used for the van Genuchten formula, the obtained compatibility between measured and calculated TAW values is very high, $R^{2}=0.884$ at $\beta=0.994$. This observation is significant from the point of view of the need to discretize the retention curve in numerical solutions of flow equations in an unsaturated soil medium. Significantly poorer fit was obtained for the Varallyay model, resulting in $R^{2}=0.229$ at $\beta=0.248$. A similar hierarchy of models is indicated by the root mean square error and coefficient of random variation. The obtained root mean square error for the Hewelke et al. as well as Genucthen-Wösten models were $S=$ 4.25 and $S=5.30$ respectively. This means that the average error of fit for these models is $V=0.22$ and $V=0.27$ of the average TAW value respectively. For the Varallyay model, this is significantly higher and amounts to 0.39 . The studies carried out confirm the local nature of pedotransfer function, which stems also from the influence of various factors other than the explanatory variables accounted for in the models. Many authors (Domżał 1979, Walczak 1984, Watts and Dexter 1997, Czyż et al. 2003) highlight the significant influence of the soil management on their retention abilities. Witkowska-Walczak (2000) and Dexter et al. (2008) indicate the aggregate structure as a factor affecting retention. The amount of water available to plants may also be shaped by the contents of specified minerals and chemical properties of soils connected with them (Kabała and Musztyfaga 2015).

\section{CONCLUSIONS}

1. The analysed soils from the Delta Vistula River area (Żuławy Wiślane) comprise alluvial soils of highly diversified physical and water retention properties. The total available water content measured according to the standard laboratory methodology ranged from $6 \%$ for sands to $33 \%$ for clays.

2. The smallest error of fit for the assessment of total available water (TAW) was obtained for the Hewelke et al. model. This amounts to $V=0.22$ with a coefficient of determination of $R^{2}=0.645$ and regression coefficient of $\beta=1.143$.

3. An especially good fit $\left(R^{2}=0.994, \beta=1.015\right)$ was observed for the van Genuchten model under the condition of applying parameters identified on the basis of the measured $\theta(h)$ function (RETC model).

4. Applying pedotransfer functions may significantly limit the time and financial outlays for the assessment of total available water. On the other hand, it should be born in mind that they have a local nature, as a result of which differences in precision of retention assessment may be significant. There is a good basis for applying these functions in practice, especially at the level of research work and large-scale projects.

\section{ACKNOWLEDGMENTS}

We thank the reviewer, the editor and the editorial office for their insightful suggestions and comments that have helped to improve the quality of the manuscript. 


\section{REFERENCES}

Brandyk T., 1988. Charakterystyczne zapasy wody w niektórych madach delty Wisły (Characteristic water reserves in some alluvial soils of the Vistula estuary). Roczniki Gleboznawcze - Soil Science Annual 39(1): 29-40.

Brogowski Z., Kwasowski W., 2015. An attempt of using soil grain size in calculating the capacity of water unavailable to plants. Soil Science Annual 66: 21-28.

Carsel R.F., Parrish R.S., 1988. Developing joint probability distributions of soil water retention characteristics. Water Resources Research 24: 755-769.

Czyż E.A., 2000. Uwilgotnienie gleb i zużycie wody przez rośliny w zależności od wybranych czynników agrotechnicznych (Soil moisture and its use by plants in relation to some agrotechnical factors). Pamiętnik Puławski 123: 143 pp.

Czyż E.A., Dexter A.R., Niedźwiecki J., 2003. Retencja wodna gleb wieloletnich statycznych doświadczeń poletkowych (Soil water retention of long-term permanent plot experiments). Roczniki Gleboznawcze - Soil Science Annual 54(3): 27-37.

Dexter A.R., Czyż E.A., Richard G., Reszkowska A., 2008. A user-friendly water retention function that takes account of the textural and structural pore spaces in soil. Geoderma 143: 243-253.

Domżał H., 1979. Wpływ zagęszczenia gleby na zawartość wody silnie związanej oraz retencję wody produkcyjnej i użytecznej (Soil condensation effect on the content of strongly bounded water and on the retention of productive and available water). Roczniki Gleboznawcze - Soil Science Annual 30(3): 45-72.

Gnatowski T., Szatyłowicz J., Brandyk T., Kechavarzi C., 2010. Hydraulic properties of fen peat soils in Poland. Geoderma 154(3-4): 188-195.

Gnatowski T., Szejba D., Oleszczuk R., Brandyk T., Sosulski T., 2006. Wpływ właściwości fizycznych i chemicznych utworów torfowych z obszaru Doliny Biebrzy na zdolności retencjonowania wody (Influence of physical and chemical properties of peat deposits from the Biebrza Valley area on water retention capacity). [W:] Brandyk T., Szajdak L., Szatyłowicz J., (eds.) Właściwości fizyczne i chemiczne gleb organicznych. Wyd. SGGW, Warszawa: 65-74.

Guber A.K., Pachepsky Y.A., 2010. Multimodelling with pedotransfer functions. Documentation and user manual for PTF calculator. Version 2.0. Environmental Microbial and Food Safety Laboratory, Hydrology and Ramote Sensing Laboratory, Beltsville Agricultural Research Center, USDA-ARS.

Hewelke P., Gnatowski T., Hewelke E., Tyszka J., Żakowicz S., 2015. Analysis of water retention capacity for select forest soils in Poland. Polish Journal of Environmental Studies 24(3): 1013-1019.

Hewelke P., Gnatowski T., Żakowicz S., 2013. The analysis of water retention capacity of mineral soils. Acta Scientiarum Polonorum Formatio Cirtcumiectus, 12(1): 43-52.

Hewelke P., Hewelke E., Chołast S., Żakowicz S., Lesak M., 2017. Assessment of the possibility of applying selected pedotransfer functions for indicating the retention of forest soils in Poland. Scientific Review - Engineering and Environmental Sciences 26(3): 336-345.

Kabała C., Musztyfaga E., 2015. Gleby płowe w systematyce gleb Polski i klasyfikacjach międzynarodowych (Clay-illuvial soils in the Polish and international soil classifications). Soil Science Annual 66(4): 204-213.
Klute A., 1986. Methods of soil analysis. Part 1. Physical and Mineralogical Methods. Agronomy Monographs no 9 ASA and SSA, Madison, Wisconsin: 635-662.

Kot S.M., Jakubowski A., Sokołowski A., 2011. Statystyka (Statistica). Wydawnictwo Difin S.A.: 325 pp.

Lamorski K., Šimunek J., Sławiński C., Lamorska J., 2017. An estimation of the main wetting branch of the soil water retention curve based on its main drying branch using the machine learning method. Water Resources Research 53: 1539-1552.

Nowicki J., Liziński T., 2004. Przyrodnicze i techniczne uwarunkowania rozwoju rolnictwa w regionie Żuław Wiślanych (Natural and technical determinants of agricultural development in the region of Żuławy Wiślane). Woda-ŚrodowiskoObszary Wiejskie 4: 1-62.

Oleszczuk R., Zając E., Hewelke E., Wawer K. 2018. Determination of water retention characteristics of organic soils, using the indirect filter-paper method. Acta Scientiarum Polonorum Formatio Circumiectus 17(2): 13-21.

Orzechowski M., Smólczyński S., Sowiński P., 2004. Zasobność mad Żuławskich w makroelementy ogólne i przyswajalne (Total and available macroelement abundance in alluvial soils of the Vistula delta). Annales Universitatis Mariae Curie-Skłodowska, Sectio E Agricultura 59(3): 1065-1071.

Pachepsky Y.A., Rawls W.J. (eds.), 2004. Development of pedotransfer functions in soil hydrology. Developments in Soil Science 30: $512 \mathrm{pp}$.

Polish Soil Classification (Systematyka Gleb Polski), 1989. Roczniki Gleboznawcze - Soil Science Annual 40(3/4): 1-150 (in Polish with English summary).

Puhlmann H., von Wilpert K., 2012. Pedotransfer functions for water retention and unsaturated hydraulic conductivity of forest soils. Journal of Plant Nutrition and Soil Science 175: 221-235.

Rawls W.J., Brakensiek D.L., 1982. Estimation soil water retention from soil properties. Journal of the Irrigation Drainage Division 108: 166-171.

Skalova J., Čistý M., Bezák J., 2011. Comparison of three regression models for determining water retention curves. Journal of Hydrology and Hydromechanics 59(4): 275-284.

Schaap M.G., Leij F.J., van Genuchten M.Th., 2001. Rosetta: a computer program for estimating soil hydraulic parameters with hierarchical pedotransfer functions. Journal of Hydrology 251: 163-176.

Trzecki S., 1974. Determination of water capacity of soils on the basis of their mechanical composition. Roczniki Gleboznawcze - Soil Science Annual (Supplement) 25: 33-44.

Trzecki S., 1976. Możliwości wyznaczania wilgotności trwałego więdnięcia roślin na podstawie maksymalnej higroskopijności i zawartości części spławianych w glebach mineralnych (Possibility of determination of the moisture of permanent wilting of plants on the basis of maximal higroscopicity and content of clayey particles in mineral soils). Roczniki Gleboznawcze - Soil Science Annual 27: 11-17.

Van Genuchten M. Th., 1980. A closed-form equation for predicting the hydraulic conductivity of unsaturated soils. Soil Science Society of America Journal 44: 892-898.

Van Genuchten M.Th., Leij F.J., Yates S.R., 1991. The RECT code for quantifying the hydraulic functions of unsaturated soils EPA/600/2-91/065.

Varallyay G., Mironienko E.V., 1979. Soil water relationships in saline and alkali conditions. [W:] Kovda V.A., Szabolces I. 
(eds.) Modeling of salinization and alkalization. Agrokemia es Talatjan 28(Supplement): 33-82.

Varallyay G., Rajkai K, Pachepsky Y.A., Shcherbakov R.A., 1982. Mathematical description of soil water retention curve (In Russian). Pochvovedenie 4: 77-89.

Vereecken, H., Maes, J., Feyen, J., Darius, P., 1989. Estimating the soil moisture retention characteristic from texture, bulk density, and carbon content. Soil Science 148: 389-403.

Vereecken H., Weynants M., Javaux M., Pachepsky Y., Schaap M.G., van Genuchten M.Th., 2010. Using pedotransfer functions to estimate the Van Genuchten-Mualem soil hydraulic properties: a review. Vadose Zone Journal 9: 1-26.

Walczak R., Witkowska-Walczak B., Sławiński C., 2004. Pedotransfer studies in Poland. Developments in Soil Science, 30: 449-463.

Walczak R., 1984. Modelowanie badania zależności retencji wodnej od parametrów fazy stałej gleby (Modeling stadies based on the parameters of the retention of solid phase of soils). Problemy Agrofizyki 41: 1-72.

Watts C.W., Dexter A.R., 1997. The influence of organic matter in reducing the destabilization of soil by simulated tillage. Soil and Tillage Research 42(4): 253-275.

Witkowska-Walczak B., 2000. Wpływ struktury agregatowej gleb mineralnych na ich hydrofizyczne charakterystyki (badania modelowe) (Influence of aggregate structure of mineral soils on their hydrophysical characteristics (Model Studies)). Acta Agrophysica 30: 5-96.

Wösten J.H.M., Lilly A., Nemes A., Le Bas C., 1999. Development and use of a database of hydraulic properties of European soils. Geoderma 90: 169-185.

,Received: December 12, 2017

Accepted: April 19, 2018

Associated editor: A. Lachacz

\section{Zastosowanie wybranych funkcji pedotransfer do wyznaczania retencji wodnej mad}

Streszczenie: Celem badań była ocena przydatności wybranych funkcji pedotransfer do obliczania retencji wodnej mad na Żuławach Wiślanych. Żuławy Wiślane stanowią ważny obszar zarówno dla produkcji rolniczej, jak i z uwagi na bogactwo środowiska przyrodniczego. W analizie uwzględniono trzy modele: van Genuchtena-Wöstena, Varellyaya i Mieronienki oraz Hewelke i in. Na podstawie 122 próbek glebowych pochodzących z 19 profili mad z obszaru Żuław analizowano związki statystyczne pomiędzy pomierzonymi wartościami potencjalnej retencji użytecznej a wartościami obliczonymi dla poszczególnych modeli. Przeprowadzone badania wykazały, że analizowane funkcje pedotransfer charakteryzują się różnym dopasowaniem do wyników uzyskiwanych na drodze pomiaru bezpośredniego. Najmniejsze średnie błędy dopasowania uzyskano dla modeli Hewelke i in. i van Genuchtena.

Słowa kluczowe: retencja wodna gleby, wilgotność gleby, potencjał macierzysty, całkowita woda dostępna, równanie regresji wielokrotnej 